Article

\title{
Expression of the Major and Pro-Oncogenic H3K9 Lysine Methyltransferase SETDB1 in Non-Small Cell Lung Cancer
}

\author{
Paola Cruz-Tapias ${ }^{1,2,3,4, *,+}$, Vlada Zakharova ${ }^{1,+}{ }^{\text {, Oscar M. Perez-Fernandez }}{ }^{5,+}$, \\ William Mantilla ${ }^{6}$, Sandra Ramírez-Clavijo ${ }^{2}$ and Slimane Ait-Si-Ali ${ }^{1, *(D)}$ \\ 1 Epigenetics and Cell Fate (EDC), Centre National de la Recherche Scientifique (CNRS), Université de Paris, \\ Université Paris Diderot, F-75013 Paris, France \\ 2 Grupo de investigación Ciencias Básicas Médicas, Faculty of Natural Sciences and Mathematics, \\ Universidad del Rosario, Bogotá 111221, Colombia \\ 3 School of Medicine and Health Sciences, Universidad del Rosario, Bogotá 111221, Colombia \\ 4 Doctoral Program in Biomedical and Biological Sciences, Universidad del Rosario, Bogotá 111221, Colombia \\ 5 Department of Cardiology, Fundación Cardioinfantil - Instituto de Cardiología, Bogotá 110131, Colombia \\ 6 Department of Hematology-oncology. Fundación Cardioinfantil - Instituto de Cardiología, \\ Bogotá 110131, Colombia \\ * Correspondence: paola.cruz@univ-paris-diderot.fr (P.C.-T.); slimane.aitsiali@univ-paris-diderot.fr (S.A.-S.); \\ Tel.: +33-(0)1-5727-8919 (S.A.-S.) \\ + These authors are equally contributed.
}

Received: 16 July 2019; Accepted: 6 August 2019; Published: 8 August 2019

\begin{abstract}
SETDB1 is a key histone lysine methyltransferase involved in gene silencing. The SETDB1 gene is amplified in human lung cancer, where the protein plays a driver role. Here, we investigated the clinical significance of SETDB1 expression in the two major forms of human non-small cell lung carcinoma (NSCLC), i.e., adenocarcinoma (ADC) and squamous cell carcinoma (SCC), by combining a meta-analysis of transcriptomic datasets and a systematic review of the literature. A total of 1140 NSCLC patients and 952 controls were included in the association analyses. Our data revealed higher levels of SETDB1 mRNA in ADC (standardized mean difference, SMD: 0.88; 95\% confidence interval, CI: $0.73-1.02 ; p<0.001$ ) and SCC (SMD: $0.40 ; 95 \%$ CI: 0.13-0.66; $p=0.003$ ) compared to non-cancerous tissues. For clinicopathological analyses, $2533 \mathrm{ADC}$ and 903 SCC patients were included. Interestingly, SETDB1 mRNA level was increased in NSCLC patients who were current smokers compared to non-smokers (SMD: 0.26 ; 95\% CI: 0.08-0.44; $p=0.004$ ), and when comparing former smokers and non-smokers $(p=0.009)$. Furthermore, the area under the curve (AUC) given by the summary receiver operator characteristic curve (sROC) was $0.774(\mathrm{Q}=0.713)$. Together, our findings suggest a strong foundation for further research to evaluate SETDB1 as a diagnostic biomarker and/or its potential use as a therapeutic target in NSCLC.
\end{abstract}

Keywords: SETDB1/KMT1E; lysine methyltransferase; non-small cell lung cancer; meta-analysis

\section{Introduction}

Lung cancer causes more than 1.6 million deaths per year worldwide, despite current progress in treatment [1]. The two major lung cancer types are non-small cell lung cancer (NSCLC) and small cell lung cancer (SCLC). The lung cancer mortality rate is driven by the high possibility of metastasis and problems in early diagnosis [2,3]. Lung cancer is a complex disease, which involves both genetic and epigenetic alterations (reviewed in [4]). 
The combined use of next-generation high-throughput sequencing (NGS) and ultra-sensitive mass spectrometry technologies has substantially improved our understanding of molecular epigenetic mechanisms, such as histone post-translational modifications (PTMs) and transcriptional regulation in normal and pathological conditions, especially in cancer. Histone PTMs are one of the most important mechanisms of epigenetic regulation of gene expression and chromatin organization. As such, histone lysine methylation is a key regulatory mechanism of chromatin organization. Histone lysine methylation status is regulated by histone lysine methyltransferases (KMTs) and lysine demethylases (KDMs). A large number of studies have substantiated the link between aberrant histone lysine methylation and malignancy, and the roles of KMTs in cancer metastasis [5]. In particular, the methylation of histone 3 lysine 9 (H3K9), which is directly involved in heterochromatin formation and both gene repression and silencing [6]. The main H3K9 KMTs, namely, G9A, GLP, SUV39H and SETDB1, are deregulated in many cancers, and variations in the global or local patterns of H3K9 methylations are found in tumor cells. For instance, abnormal H3K9 methylations have been associated with poor survival and higher risk of relapse [7]. A loss of H3K9 dimethylation (H3K9me2) has been found in prostate, lung and kidney cancer patients [8,9], and H3K9me3 is a diagnostic marker of metastasis in lung cancer patients [10]. In addition, mutations in KMT genes or abnormal expression of KMTs are found in tumors [11].

SETDB1 (also named KMT1E) is a major H3K9 KMT known to be required for mammalian development as it regulates pluripotency in the early embryo [12], stem cell potential and terminal differentiation in many progenitor cell types $[13,14]$. SETDB1 is central in embryonic stem cell (ESC) pluripotency and self-renewal [15-17] and in many adult stem cells. Interestingly, tumors consist of heterogeneous cell populations and a subset of cells, so called cancer stem cells (CSCs), which express pluripotency markers and have the ability for self-renewal, such as ESCs. CSCs have been proposed as an origin for certain types of tumors, and the expression of pluripotency markers might hereby play a role [18]. Thus, SETDB1 key roles in stemness regulation may provide a link between ESCs and CSCs biology. We participated in a study showing that the human SETDB1 gene is amplified in melanoma, in which SETDB1 accelerates tumorigenesis [19].

Furthermore, SETDB1 is overexpressed in lung cancer [20] and silences certain genes by direct interaction with the DNA methyltransferase DNMT3A [21], and both are implicated in epithelial-to-mesenchymal transition (EMT) and metastasis [22]. Most interestingly, an amplification of the SETDB1 gene was also described in lung cancer, in which SETDB1 is considered as a pro-oncogene able to increase tumor invasion [23]. The SETDB1 gene was found to be amplified in lung cancer cell lines and primary tumors [23]. The same study showed that the SETDB1 gene is amplified several times in human NSCLC and SCLC cell lines and in primary lung tumors. The authors observed an increase in SETDB1 copy number. Importantly, SETDB1 protein overexpression was associated with elevated cell growth rates and the invasive potential of cancer cells in nude mouse models [23]. High levels of SETDB1 expression are also associated with poor prognosis in terms of overall survival of patients [24]. SETDB1 hyperactivation affects various signaling pathways such as WNT, MAPK, Toll-like receptors (TLRs), focal adhesion, and JAK-STAT pathways in lung cancer cells [24].

Here, we tested the clinical significance of SETDB1 expression in NSCLC, based on the analysis of large-scale transcriptomic datasets. To this end, we conducted different meta-analyses using 45 microarray datasets from the Gene Expression Omnibus (GEO) database. Furthermore, summary receiver operator characteristic curve (sROC) analysis was used to determine the discriminative yield of SETDB1 expression in NSCLC. In parallel, a systematic review of the literature was conducted up to April 2019 to provide information about the association of SETDB1 expression and NSCLC. Our results showed higher levels of SETDB1 mRNA in both ADC and SCC tissues compared to non-cancerous tissue controls. Interestingly, SETDB1 mRNA level was increased in former or current smoker NSCLC patients compared to non-smokers.

Our findings suggest that SETDB1 expression levels could be used as a diagnostic biomarker and/or potentially be used as a therapeutic target in NSCLC. 


\section{Results}

\subsection{Association Between SETDB1 Expression and NSCLC}

Our initial search strategy identified 1247 microarray datasets (Figure 1). After screening and eligibility assessment, we included a total of 20 datasets reporting expression levels of SETDB1 mRNA in cancerous and adjacent non-cancerous specimens that were resected from NSCLC patients. In addition, a total of five datasets reporting expression levels of SETDB1 in cancerous specimens from NSCLC patients and normal specimens from a healthy control group were included for meta-analysis. The main characteristics of the elected studies are described in Table 1.

Overall, 1140 NSCLC cases and 952 controls were analyzed. The expression of SETDB1 was significantly increased in NSCLC tissues compared to normal lung tissues (SMD: 0.66; 95\% CI: 0.52-0.80; $p<0.001)$ with moderate heterogeneity $\left(I^{2}=54.4 \% ; p<0.001\right)$ (Figure $\left.2 \mathrm{~A}\right)$. Independent analyses of the association between SETDB1 mRNA levels and NSCLC for each GEO dataset are presented in the Supplementary Figure S1. There was no evidence of publication bias based on the funnel plot and Egger's test, as seen in Supplementary Figure S2A.

Subgroup analyses were performed for the most common subtypes of NSCLC, namely, adenocarcinoma (ADC) and squamous cell carcinoma (SCC). Interestingly, the expression of SETDB1 was significantly increased in both, tissues from patients with ADC (SMD: 0.88; 95\% CI: 0.73-1.02; $p<0.001$ ) as well as SCC (SMD: $0.40 ; 95 \%$ CI: 0.13-0.66; $p=0.003$ ) compared to non-cancerous lung tissues (Figure 2B,C). The heterogeneity was moderate for ADC $\left(I^{2}=30.7 \% ; p=0.09\right)$ and SCC $\left(I^{2}=37.8 \% ; p=0.09\right)$. There was no evidence of publication bias based on the funnel plot and Egger's test (Figure S2B,C).

Thus, a global increase in SETDB1 mRNA level seems to be a hallmark of NSCLC, both of ADC and SCC subtypes. 
Workflow of the included GEO datasets

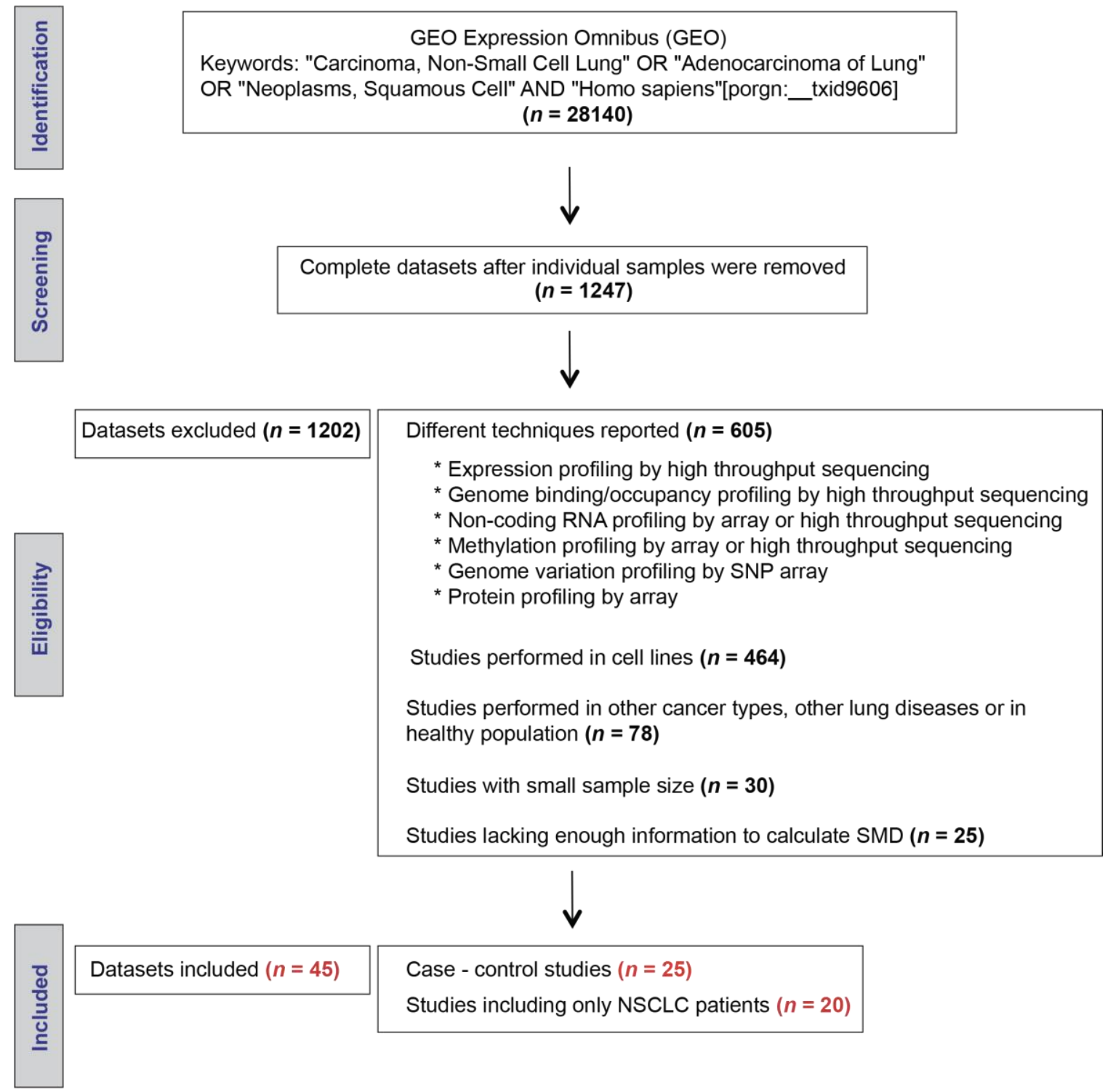

Figure 1. Workflow of the included Gene Expression Omnibus (GEO) datasets. 
Table 1. Overview of the datasets selected from GEO for case-control analyses.

\begin{tabular}{|c|c|c|c|c|c|c|c|c|c|c|c|}
\hline $\begin{array}{c}\text { GEO } \\
\text { Dataset }\end{array}$ & Country & Year & ADC & SCC & NSCLC * & Controls & $\begin{array}{l}\text { Sample Type in } \\
\text { Patients }\end{array}$ & Sample Type in Controls & Platform & SETDB1 ID & Reference \\
\hline GSE32867 & Canada & 2012 & 58 & & & 58 & Cancer tissue & $\begin{array}{l}\text { Adjacent non-cancerous } \\
\text { tissues }\end{array}$ & $\begin{array}{l}\text { Illumina Human WG-6 v3.0 } \\
\text { Expression BeadChips }\end{array}$ & ILMN_1718207 & [25] \\
\hline GSE18842 & Spain & 2010 & 14 & 31 & & 46 & Cancer tissue & $\begin{array}{l}\text { Adjacent non-cancerous } \\
\text { tissues }\end{array}$ & $\begin{array}{l}\text { Affymetrix Human Genome } \\
\text { U133 Plus 2.0 Array }\end{array}$ & 203155_at & [26] \\
\hline GSE19804 & Taiwan & 2010 & & & 60 & 60 & Cancer tissue & $\begin{array}{l}\text { Adjacent non-cancerous } \\
\text { tissues }\end{array}$ & $\begin{array}{l}\text { Affymetrix GeneChip Human } \\
\text { Genome U133 plus array }\end{array}$ & 203155_at & [27] \\
\hline GSE103512 & Germany & 2017 & 30 & 25 & & 14 & Cancer tissue & $\begin{array}{c}\text { Adjacent non-cancerous } \\
\text { tissues }\end{array}$ & $\begin{array}{c}\text { Affymetrix } \\
\text { HT-U133plus-2-PM } \\
\text { microarrays }\end{array}$ & 203155_PM_at & [28] \\
\hline GSE63459 & USA/Japan & 2015 & 33 & & & 32 & Cancer tissue & $\begin{array}{l}\text { Adjacent non-cancerous } \\
\text { tissues }\end{array}$ & $\begin{array}{l}\text { Illumina HumanRef-8 v3 } \\
\text { Expression Beadchip arrays }\end{array}$ & ILMN_1718207 & [29] \\
\hline GSE75037 & USA & 2016 & 83 & & & 83 & Cancer tissue & $\begin{array}{l}\text { Adjacent non-cancerous } \\
\text { tissues }\end{array}$ & $\begin{array}{l}\text { Illumina BeadChip array } \\
\text { HumanWG-6 V3 }\end{array}$ & ILMN_1718207 & {$[30]$} \\
\hline GSE33532 & Germany & 2014 & 10 & 4 & 6 & 20 & Cancer tissue & $\begin{array}{c}\text { Adjacent non-cancerous } \\
\text { tissues }\end{array}$ & $\begin{array}{c}\text { Affymetrix U133 Plus } 2.0 \\
\text { arrays }\end{array}$ & 203155_at & [31] \\
\hline GSE44077 & USA & 2013 & 14 & 5 & 2 & 21 & Cancer tissue & $\begin{array}{l}\text { Adjacent non-cancerous } \\
\text { tissues }\end{array}$ & $\begin{array}{c}\text { Affymetrix Human Gene } 1.0 \\
\text { ST Array [transcript (gene) } \\
\text { version] }\end{array}$ & 7905258 & [32] \\
\hline GSE43458 & USA & 2013 & 80 & & & 30 & Cancer tissue & $\begin{array}{l}\text { Adjacent non-cancerous } \\
\text { tissues }\end{array}$ & $\begin{array}{c}\text { Affymetrix Human Gene } 1.0 \\
\text { ST Array [transcript (gene) } \\
\text { version] }\end{array}$ & 7905258 & [33] \\
\hline GSE21933 & USA/Taiwan & 2012 & 11 & 10 & & 21 & Cancer tissue & $\begin{array}{c}\text { Adjacent non-cancerous } \\
\text { tissues }\end{array}$ & Phalanx Human OneArray & PH_hs_0023897 & [34] \\
\hline GSE31552 & USA & 2014 & 21 & 9 & 2 & 32 & Cancer tissue & $\begin{array}{c}\text { Adjacent non-cancerous } \\
\text { tissues }\end{array}$ & $\begin{array}{c}\text { Affymetrix Human Gene } 1.0 \\
\text { ST Array [transcript (gene) } \\
\text { version] }\end{array}$ & 7905258 & [35] \\
\hline GSE10072 & Italy & 2008 & 58 & & & 49 & Cancer tissue & Healthy lung tissues & $\begin{array}{c}\text { Affymetrix Human Genome } \\
\text { U133A Array }\end{array}$ & 203155_at & {$[36]$} \\
\hline GSE4115 & USA & 2007 & & & & 90 & Cancer tissue & Healthy lung tissues & $\begin{array}{l}\text { Affymetrix Human Genome } \\
\text { U133A Array }\end{array}$ & 203155_at & [37] \\
\hline GSE31547 & USA & 2018 & 30 & & & 20 & Cancer tissue & $\begin{array}{l}\text { Adjacent non-cancerous } \\
\text { tissues }\end{array}$ & $\begin{array}{c}\text { Affymetrix Human Genome } \\
\text { U133A Array }\end{array}$ & 203155_at & Notpublished \\
\hline GSE7670 & Taiwan & 2007 & 26 & & & 27 & Cancer tissue & $\begin{array}{l}\text { Adjacent non-cancerous } \\
\text { tissues }\end{array}$ & $\begin{array}{c}\text { Affymetrix Human Genome } \\
\text { U133A Array }\end{array}$ & 203155_at & {$[38]$} \\
\hline GSE2514 & USA & 2005 & 20 & & & 19 & Cancer tissue & $\begin{array}{c}\text { Adjacent non-cancerous } \\
\text { tissues }\end{array}$ & $\begin{array}{l}\text { Affymetrix GeneChip } \\
\text { microarray (HGU95Av2) }\end{array}$ & 34189_at & [39] \\
\hline
\end{tabular}


Table 1. Cont.

\begin{tabular}{|c|c|c|c|c|c|c|c|c|c|c|c|}
\hline $\begin{array}{c}\text { GEO } \\
\text { Dataset }\end{array}$ & Country & Year & ADC & SCC & NSCLC* & Controls & $\begin{array}{l}\text { Sample Type in } \\
\text { Patients }\end{array}$ & Sample Type in Controls & Platform & SETDB1 ID & Reference \\
\hline GSE11117 & Switzerland & 2010 & 13 & 14 & & 15 & Cancer tissue & $\begin{array}{l}\text { Chronic inflammatory } \\
\text { lung disease tissues }\end{array}$ & $\begin{array}{c}\text { Nova Chip microarrays } \\
\text { (Novartis) }\end{array}$ & H200002955 & [40] \\
\hline GSE1987 & Israel & 2006 & & & 28 & 9 & Cancer tissue & Healthy lung tissues & $\begin{array}{c}\text { Affymetrix Human Genome } \\
\text { U95A Array }\end{array}$ & 34189_at & [41] \\
\hline GSE19188 & Netherlands & 2010 & 45 & 27 & & 65 & Cancer tissue & $\begin{array}{l}\text { Adjacent non-cancerous } \\
\text { tissues }\end{array}$ & $\begin{array}{l}\text { Affymetrix Human Genome } \\
\text { U133 Plus 2.0 Array }\end{array}$ & 203155_at & [42] \\
\hline GSE74706 & Germany & 2016 & 10 & 8 & & 18 & Cancer tissue & $\begin{array}{l}\text { Adjacent non-cancerous } \\
\text { tissues }\end{array}$ & $\begin{array}{c}\text { Agilent-026652 Whole } \\
\text { Human Genome Microarray } 4 \\
\times 44 \mathrm{~K} \text { v2 }\end{array}$ & A_23_P126393 & [43] \\
\hline GSE46539 & Taiwan & 2015 & 115 & & & 115 & Cancer tissue & $\begin{array}{l}\text { Adjacent non-cancerous } \\
\text { tissues }\end{array}$ & $\begin{array}{l}\text { Illumina WG-DASL } \\
\text { HumanRef8 v3 or } \\
\text { HumanHT12 v4 BeadChip }\end{array}$ & ILMN_1718207 & [44] \\
\hline GSE2088 & Japan & 2011 & 9 & 48 & & 30 & Cancer tissue & $\begin{array}{l}\text { Healthy lung tissues } \\
\text { Adjacent non-cancerous }\end{array}$ & $\begin{array}{l}\text { CHUGAI 41K microarray } \\
\text { Agilent-012391 Whole }\end{array}$ & 11758 & [45] \\
\hline GSE12428 & Netherlands & 2008 & & 34 & & 28 & Cancer tissue & $\begin{array}{l}\text { tissues/Healthy lung } \\
\text { tissues }\end{array}$ & $\begin{array}{l}\text { Human Genome Oligo } \\
\text { Microarray G4112A }\end{array}$ & 7231 & [46] \\
\hline GSE27262 & Taiwan & 2012 & 25 & & & 25 & Cancer tissue & $\begin{array}{l}\text { Adjacent non-cancerous } \\
\text { tissues }\end{array}$ & $\begin{array}{l}\text { Affymetrix Human Genome } \\
\text { U133 Plus } 2.0 \text { Array }\end{array}$ & 203155_at & [47] \\
\hline GSE101929 & USA & 2017 & & & 25 & 25 & Cancer tissue & $\begin{array}{c}\text { Adjacent non-cancerous } \\
\text { tissues }\end{array}$ & $\begin{array}{l}\text { Affymetrix Human Genome } \\
\text { U133 Plus } 2.0 \text { Array }\end{array}$ & 203155_at & [48] \\
\hline
\end{tabular}

* Non-small cell lung carcinoma (NSCLC): Patients are not classified as adenocarcinoma (ADC) or squamous cell carcinoma (SCC). 
A.

\begin{tabular}{lccccccc}
\multicolumn{1}{c}{ Study } & $\begin{array}{c}\text { Std diff } \\
\text { in means }\end{array}$ & $\begin{array}{c}\text { Lower } \\
\text { limit }\end{array}$ & $\begin{array}{c}\text { Upper } \\
\text { limit }\end{array}$ & $p$-Value & Weight & Std diff in means and 95\% Cl \\
\hline GSE32867 & 0.74 & 0.37 & 1.12 & $<0.001$ & $5.04 \%$ &
\end{tabular}

B.

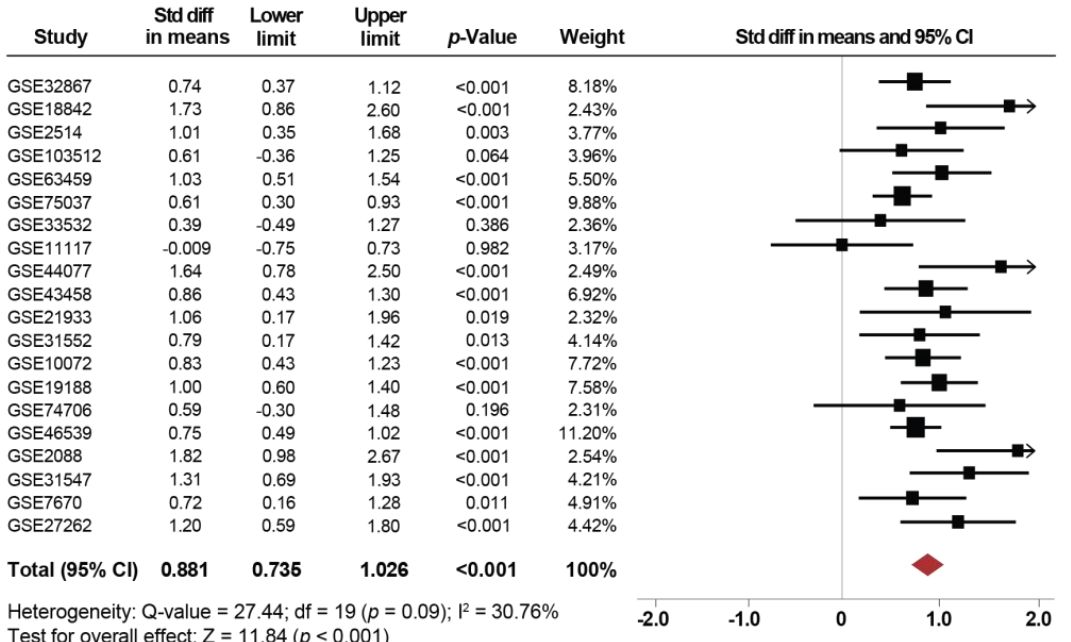

c.

\begin{tabular}{|c|c|c|c|c|c|c|}
\hline Study & $\begin{array}{l}\text { Std diff } \\
\text { in means }\end{array}$ & $\begin{array}{c}\text { Lower } \\
\text { limit }\end{array}$ & $\begin{array}{l}\text { Upper } \\
\text { limit }\end{array}$ & $p$-Value & Weight & Std diff in means and $95 \% \mathrm{Cl}$ \\
\hline GSE18842 & 1.04 & 0.52 & 1.57 & $<0.001$ & $12.96 \%$ & $\longrightarrow$ \\
\hline GSE103512 & -0.07 & -0.72 & 0.58 & 0.827 & $10.17 \%$ & \\
\hline $\begin{array}{l}\text { GSE33532 } \\
\text { GEE11117 }\end{array}$ & $\begin{array}{l}0.44 \\
0.28\end{array}$ & $\begin{array}{l}-0.95 \\
-101\end{array}$ & $\begin{array}{l}1.85 \\
0.44\end{array}$ & $\begin{array}{l}0.531 \\
0.447\end{array}$ & $\begin{array}{l}3.18 \% \\
88.8 \%\end{array}$ & - \\
\hline GSE44077 & 1.00 & -0.31 & 2.32 & 0.135 & $\begin{array}{l}0.02 \% \\
3.56 \%\end{array}$ & \\
\hline $\begin{array}{l}\text { GSE21933 } \\
\text { GSE31552 }\end{array}$ & 0.94 & $\begin{array}{c}0.02 \\
-0.21\end{array}$ & $\begin{array}{l}1.86 \\
1.69\end{array}$ & $\begin{array}{l}0.045 \\
0.129\end{array}$ & $\begin{array}{l}6.33 \% \\
602 \%\end{array}$ & \\
\hline $\begin{array}{l}\text { GSE19188 } \\
\text { GSE }\end{array}$ & 0.32 & $\begin{array}{l}-0.21 \\
-0.12\end{array}-12$ & 0.77 & 0.161 & $14.97 \%$ & \\
\hline GSE74706 & 0.38 & -0.60 & 1.37 & 0.443 & $5.70 \%$ & \\
\hline GSE2088 & & 0.004 & 0.92 & 0.048 & $14.67 \%$ & \\
\hline GSE12428 & 0.03 & -0.46 & 0.53 & 0.899 & $13.64 \%$ & \\
\hline Total $(95 \% \mathrm{Cl})$ & 0.401 & 0.134 & 0.668 & 0.003 & $100 \%$ & \\
\hline
\end{tabular}

Figure 2. SETDB1 mRNA expression is significantly increased in NSCLC patients. (A) Forest plot of standardized mean difference (SMD) comparing SETDB1 mRNA levels in NSCLC patients and non-cancerous controls, including adjacent non-cancerous specimens that were resected from NSCLC patients or normal specimens from a healthy control. (B) and (C) Subgroup meta-analysis of the SETDB1 mRNA levels between ADC patients (B) and SCC patients (C) compared to non-cancerous controls. Standardized mean differences for each dataset are represented by the squares, and the horizontal line crossing the square represents the $95 \%$ CI. The diamonds represent the estimated overall effect. The arrows indicate that the upper limit of the SMD is higher than 2. 


\subsection{Expression of SETDB1 Is Increased in Current and Former Smokers Compared to NSCLC} Non-Smoker Patients

Since tobacco use is the leading cause of lung cancer [1], we next investigated whether the expression of SETDB1 is associated with smoking in NSCLC. Thus, we compared the changes in SETDB1 mRNA levels between current, former and non-smoker NSCLC patients. Twelve microarray datasets, including 297 current smoker, 547 former smoker and 220 non-smoker NSCLC patients were used in this meta-analysis. Our results showed that SETDB1 mRNA levels were increased in tissues from NSCLC patients who were current smokers compared to non-smokers (SMD: 0.26; 95\% CI: $0.08-0.44 ; p=0.004)$, with low heterogeneity $\left(I^{2}=11 \% ; p=0.33\right)$ (Figure $\left.3 \mathrm{~A}\right)$. Furthermore, the same association was found when comparing NSCLC tissues from former smokers and non-smokers (SMD: 0.26; 95\% CI: $0.06-0.46 ; p=0.009)$, with low heterogeneity $\left(I^{2}=0 \% ; p=0.80\right)$ (Figure 3B). In addition, for 12 datasets reporting only whether the patients were smokers or non-smokers, an independent analysis was performed, showing that SETDB1 mRNA levels were higher in smokers (SMD: 0.19; $95 \%$ CI: $0.05-0.33 ; p=0.006)$, with low heterogeneity $\left(I^{2}=0 \% ; p=0.503\right)$ (Figure S3A). There was no evidence of publication bias based on the funnel plot and Egger's test (Figure S2D-F).

Furthermore, to evaluate whether the association of SETDB1 mRNA levels with smoking status correlated with a cancer subtype, subgroup analyses were performed for ADC patients. Herein, SETDB1 mRNA expression was higher in tissues from patients with ADC who were current smokers compared to non-smokers (SMD: $0.35 ; 95 \%$ CI: $0.03-0.67 ; p=0.027)$, with moderate heterogeneity $\left(I^{2}=44.3 \%\right.$; $p=0.072$ ). Also, a trend was observed, approaching statistical significance, showing an increase in expression levels of SETDB1 in ADC tissues from former smokers (SMD: 0.25; 95\% CI: -0,005-0.52; $p=0.055)$, with low heterogeneity $\left(I^{2}=21.2 \% ; p=0.26\right)$. Subgroup analyses for SCC patients were not possible because of an insufficient number of non-smoker patients. There was no evidence of publication bias based on the funnel plot and Egger's test.

Finally, there were no clinical or pathological characteristics (gender, age and clinical stage) associated with the smoking status of the NSCLC patients and the increase in SETDB1 expression levels (Table 2).

Together, these data indicate that higher levels of SETDB1 mRNA correlate with the patient's smoking history status.

A.

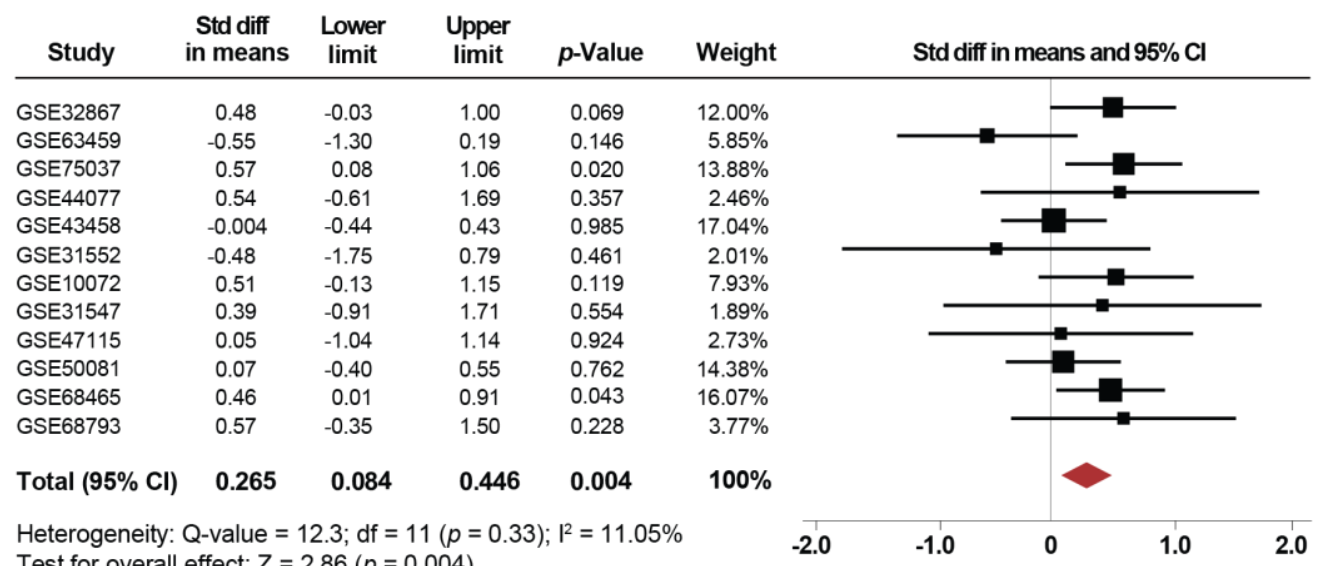

Figure 3. Cont. 
B.

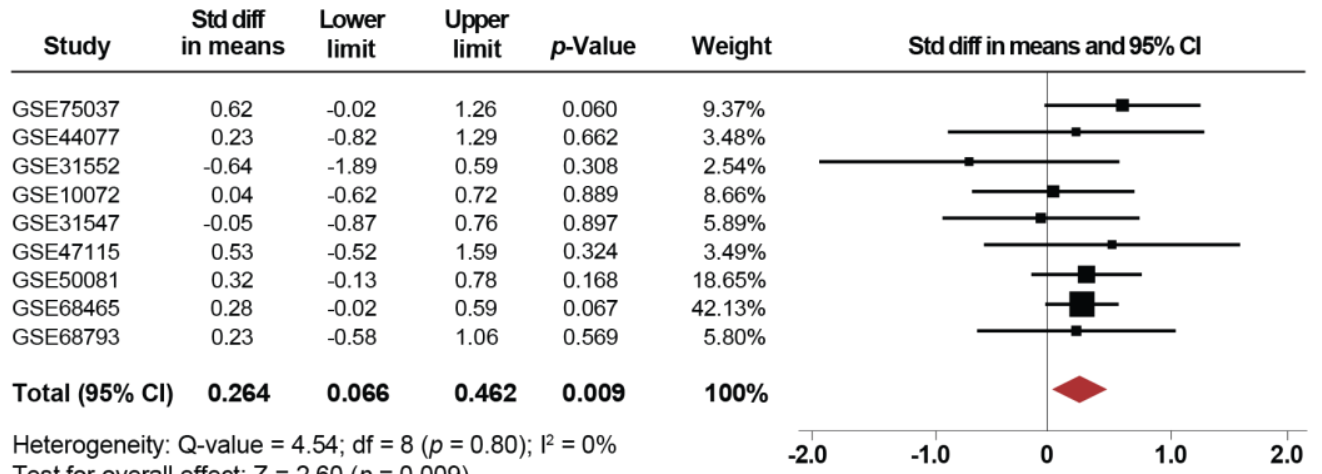

Figure 3. Upregulation of SETDB1 mRNA is correlated with smoking history. (A) Forest plot of overall analysis of SETDB1 mRNA expressions between NSCLC patients reported as current smokers compared to non-smoker patients. (B) Forest plot of overall analysis of SETDB1 mRNA expressions between NSCLC patients reported as former smokers compared to non-smoker patients. Standardized mean differences (SMD) for each dataset are represented by the squares, and the horizontal line crossing the square represents the $95 \% \mathrm{CI}$. The diamonds represent the estimated overall effect.

\subsection{Association Between SETDB1 Levels and Pathological Characteristics of the NSCLC Samples}

Overall, 34 microarray datasets containing information about pathological characteristics were analyzed (Table 1 and Table S1). There was no statistical evidence that pathological stages or tumor-node-metastasis (TNM) stages in ADC and SCC have an association with the expression levels of SETDB1 (Table 2). However, as shown in Supplementary Figure S3B, a possible trend toward significance showing an association between SETDB1 expression and NSCLC patients carrying mutations for the TP53 gene was observed (SMD: 0.15; 95\% CI: $-0.004-0.31 ; p=0.052$ ), with low heterogeneity $\left(I^{2}=0 \% ; p=0.60\right)$. There was no evidence of publication bias based on the funnel plot and Egger's test (Figure S2G). No associations were found between SETDB1 expression and NSCLC patients carrying mutations for neither the Epidermal Growth Factor Receptor (EGFR) nor the KRAS oncogenes (Table 2).

Collectively, these findings suggest that high levels of SETDB1 mRNA are not dependent on an NSCLC patient's gender or age and are maintained at every clinical stage during the carcinogenic process.

Table 2. Analysis of the association between SETDB1 mRNA expression and clinical and pathological characteristics.

\begin{tabular}{ccccc}
\hline Characteristics & Std Diff in Means & Lower Limit & $\begin{array}{c}\text { Upper } \\
\text { Limit }\end{array}$ & $p$-Value \\
\hline $\begin{array}{c}\text { Clinical Characteristics } \\
\text { Size and extent of the main tumor (T) }\end{array}$ & & & & \\
ADC T1 vs. T2/T3/T4 & -0.03 & -0.156 & 0.096 & 0.636 \\
SCC T1 vs. T2/T3/T4 & 0.077 & -0.192 & 0.346 & 0.574 \\
Spread to nearby lymph nodes (N) & & & & \\
ADC N0 vs. N1/N2/N3 & 0.028 & -0.21 & 0.266 & 0.82 \\
SCC N0 vs. N1/N2/N3 & 0.075 & -0.137 & 0.287 & 0.489 \\
$\quad$ Stage of cancer & -0.023 & -0.129 & 0.083 & 0.666 \\
ADC 1 vs. 2/3/4 & -0.038 & -0.179 & 0.103 & 0.596 \\
SCC 1 vs. 2/3/4 & & & & \\
Presence of mutations in genes & 0.088 & -0.116 & 0.291 & 0.399 \\
EGFR & 0.114 & -0.114 & 0.342 & 0.326 \\
KRAS & & &
\end{tabular}


Table 2. Cont.

\begin{tabular}{ccccc}
\hline Characteristics & Std Diff in Means & Lower Limit & $\begin{array}{c}\text { Upper } \\
\text { Limit }\end{array}$ & $p$-Value \\
\hline Smoking Status & & & & 0.918 \\
NSCLC-Age & 0.007 & -0.125 & 0.139 & 0.857 \\
NSCLC-Gender & 0.013 & -0.131 & 0.158 & 0.853 \\
ADC-Age & 0.011 & -0.106 & 0.128 & 0.906 \\
ADC-Gender & 0.012 & -0.184 & 0.208 & 0.119 \\
ADC-Stage 1 vs. 2/3/4 & -0.106 & -0.239 & 0.027 & 0.505 \\
SCC-Age & 0.07 & -0.137 & 0.277 & 0.441 \\
SC-Gender & -0.096 & -0.339 & 0.148 & 0.619 \\
\hline
\end{tabular}

\subsection{Diagnostic Value of SETDB1 in NSCLC, Based on Meta-Analysis}

A summary receiver operator characteristic curve (sROC) analysis was carried out to determine the discriminative yield of SETDB1 mRNA level in NSCLC. A total of 1140 patients from 25 GEO microarray datasets were included in this analysis. Detailed information and independent ROC curves of each record are presented in Supplementary Figure S4. The overall combined area under the sROC curve was 0.774 (Standard Error, $\mathrm{SE}=0.031$ ), and the diagnostic odds ratio was 6.69 (95\% CI: 3.96-11.29), with high heterogeneity $\left(I^{2}=83.8 \% ; p<0.0001\right)$ (Figure 4$)$. The combined sensitivity and specificity were 0.69 (95\% CI: 0.66-0.72) and 0.71 (95\% CI: 0.68-0.74), respectively (Figure S5), with a pooled LR+ of 2.55 (95\% CI: 1.95-3.35) and a pooled LR- of 0.41 (95\% CI: 0.32-0.53).

Altogether, our analyses revealed that SETDB1 expression yielded a moderate prediction value for NSCLC.

A.

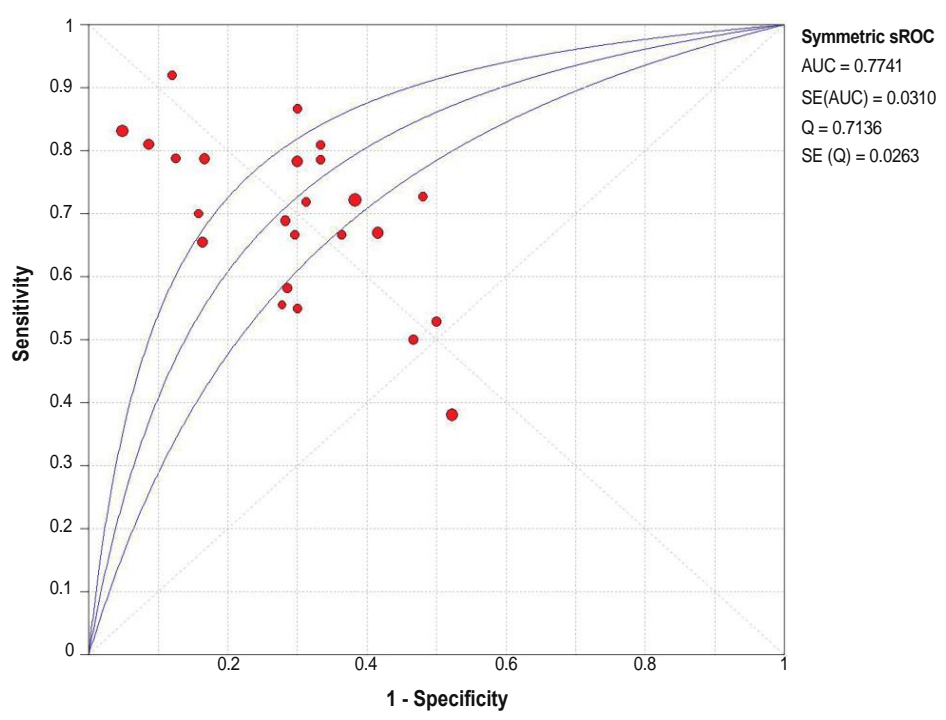

Figure 4. Cont. 
B.

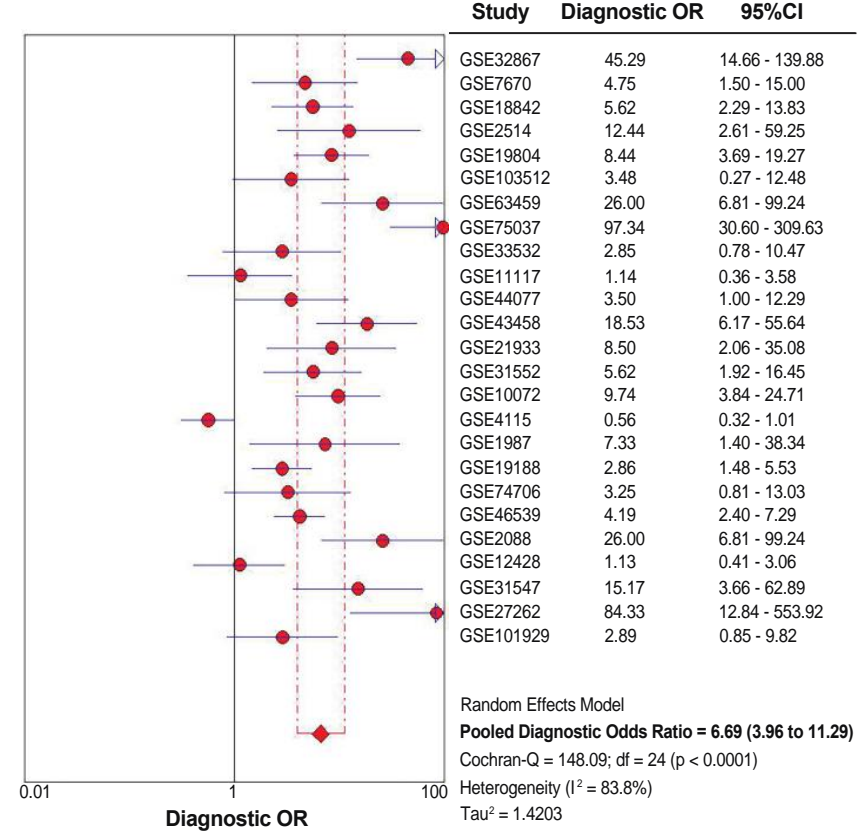

Figure 4. Summary receiver operator characteristic curve (sROC) and diagnostic odds ratio (OR), showing a moderate discriminative yield of SETDB1 mRNA expression for NSCLC. (A) Symmetrical summary receiver operator characteristic curve (sROC) based on 1140 NSCLC tissues and 952 non-cancerous tissues (25 GEO datasets). The size of the circle symbolizes the sample size of each study included in the meta-analysis. (B) Forest plot for diagnostic odds ratios in NSCLC diagnosis. The circles represent odds ratios for each dataset. The diamond represents the estimated overall effect, based on the meta-analysis random-effect method.

\subsection{Literature Review on SETDB1 in NSCLC}

A total of 13 records were retrieved from the databases Pubmed, EBI-EMBL, Web of Science, Embase, Bibliovie and Cochrane Library (Figure S6). The main results are recapitulated in Table 3 and Supplementary Table S2. In summary, the studies used more than 20 lung cancer cell lines, primary tissues and xenograft models.

Concerning the analysis of SETDB1 status in primary tissues, there are seven studies reporting the association of SETDB1 with the carcinogenic process in lung cancer (Table 3). Thus, the SETDB1 gene is amplified in NSCLC tissues [23,24] and could be considered as a marker of a shorter survival period in ADC patients [49]. Moreover, SETDB1 mRNA levels were higher in tissues from NSCLC patients compared to non-tumor tissues [24,50,51], and this increase was associated with advanced grade NSCLC tumors [24], shorter overall survival in NSCLC patients [50] and shorter disease-free survival in NSCLC patients in stage I [51]. Interestingly, the amplification of the SETDB1 gene was correlated with high SETDB1 mRNA levels [23,24] and protein overexpression in NSCLC tissues [23]. Finally, SETDB1 protein levels were higher in tissues from lung cancer patients compared to non-tumor tissues $[24,50,52]$. Sun et al. reported a possible trend correlating SETDB1 expression with an advanced pathological state [24]. However, Wu et al. observed a higher expression of SETDB1 during the early stages of lung cancer [52].

In addition, ten studies reported the pro-oncogenic role of SETDB1 in lung carcinogenesis, based on cell lines and xenograft models (Table S2). In general, SETDB1 is associated with the regulation of cell proliferation, cellular invasion [20,23,24,52] and apoptosis [53]. Moreover, SETDB1 participates during the oncogenic process by the activation of different pathways, including WNT [24] and AKT, [50] or by the regulation of miRNAs, such as the miR-29 family [54]. Finally, three studies reported results highlighting the possible therapeutic targeting of SETDB1 during lung cancer treatment [55-57]. 
Table 3. Literature review on SETDB1 status in primary lung cancer tissues.

\begin{tabular}{|c|c|c|c|c|}
\hline Study & Study Design and Subjects & Main Findings & Methods and Analysis & Conclusions \\
\hline Wu et al. 2014 [52] & $\begin{array}{c}\text { Primary tumors of lung cancer patients at different } \\
\text { clinical stages }(n=192) \text { and adjacent normal } \\
\text { tissues }(n=16) .\end{array}$ & $\begin{array}{l}\text { SETDB1 protein levels were elevated in lung } \\
\text { cancer tissues compared to non-tumor tissues. } \\
\text { Possible association with early stages. }\end{array}$ & IHC, tissue microarray & $\begin{array}{l}\text { SETDB1 is highly expressed in } \\
\text { lung cancer. }\end{array}$ \\
\hline $\begin{array}{l}\text { Rodriguez-Paredes et al. } \\
\qquad 2014[23]\end{array}$ & $\begin{array}{c}\text { Primary ADC }(n=20), \operatorname{SCC}(n=20), \operatorname{SCLC}(n=19) \\
\text { tissues. }\end{array}$ & $\begin{array}{c}\text { Amplification of the SETDB1 gene correlates with } \\
\text { elevated SETDB1 transcripts and protein } \\
\text { overexpression in tissues from patients with } \\
\text { NSCLC and SCLC. }\end{array}$ & FISH, qPCR, IHC & $\begin{array}{l}\text { SETDB1 is amplified and highly } \\
\text { expressed in NSCLC and SCLC. }\end{array}$ \\
\hline \multirow{3}{*}{ Sun et al. 2015 [24] } & TCGA ADC dataset. & $\begin{array}{l}\text { Amplification of SETDB1 loci correlates with } \\
\text { elevated SETDB1 transcripts. }\end{array}$ & Bioinformatics & \multirow{3}{*}{$\begin{array}{l}\text { SETDB1 is amplified and highly } \\
\text { expressed in NSCLC. }\end{array}$} \\
\hline & $\begin{array}{l}\text { Eight microarrays from GEO and Expression Atlas } \\
\text { databases. Primary NSCLC }(n=60) \text { and their } \\
\text { paired adjacent normal tissues }(n=60) .\end{array}$ & $\begin{array}{l}\text { SETDB1 mRNA levels were higher in NSCLC } \\
\text { tissues compared to non-tumor tissues. Elevated } \\
\text { expression of SETDB1 correlates with advanced } \\
\text { grade tumors. }\end{array}$ & Bioinformatics, RT-qPCR & \\
\hline & $\begin{array}{l}\text { Lung cancer tissues ( } n=387) \text { and normal } \\
\text { bronchial epithelium cells }(n=106) .\end{array}$ & $\begin{array}{l}\text { SETDB1 protein levels were elevated in lung } \\
\text { cancer tissues compared to non-tumor tissues. } \\
\text { Possible association with an advanced } \\
\text { pathological stage. }\end{array}$ & IHC, tissue microarray & \\
\hline \multirow{3}{*}{ Inoue et al. 2015 [49] } & Primary ADC $(n=164)$ and SCC $(n=99)$ tissues. & $\begin{array}{l}\text { High-level amplification of the SETDB1 gene in } \\
\text { ADC tissues was associated with an advanced } \\
\text { pathological stage. }\end{array}$ & FISH & \multirow{3}{*}{$\begin{array}{l}\text { SETDB1 gene amplification is a } \\
\text { marker of poor survival in ADC }\end{array}$} \\
\hline & & $\begin{array}{l}\text { Low-level amplification of the SETDB1 gene was } \\
\text { observed in SCC tissues. }\end{array}$ & FISH & \\
\hline & & $\begin{array}{l}\text { SETDB1 gene amplification was associated with } \\
\text { shorter postoperative overall survival in ADC } \\
\text { patients. }\end{array}$ & Kaplan-Meier analysis & \\
\hline $\begin{array}{l}\text { Lafuente-Sanchis et al. } \\
2015[51]\end{array}$ & $\begin{array}{c}\text { Stage I primary NSCLC }(n=64) \text { and adjacent } \\
\text { normal tissues. }\end{array}$ & $\begin{array}{c}\text { SETDB1 mRNA was upregulated in primary } \\
\text { NSCLC tissues. High SETDB1 mRNA levels were } \\
\text { associated with a shorter disease-free survival in } \\
\text { stage I NSCLC. }\end{array}$ & $\begin{array}{l}\text { RT-qPCR, Kaplan-Meier } \\
\text { analysis }\end{array}$ & $\begin{array}{l}\text { High mRNA levels of SETDB1 } \\
\text { as a prognostic marker of a } \\
\text { shorter disease-free survival. }\end{array}$ \\
\hline
\end{tabular}


Table 3. Cont.

\begin{tabular}{|c|c|c|c|c|}
\hline Study & Study Design and Subjects & Main Findings & Methods and Analysis & Conclusions \\
\hline Chen et al. 2018 [54] & $\begin{array}{l}\text { Stage III and IV primary NSCLC tissues }(n=30) \\
\text { and paired adjacent normal tissues }(n=30)\end{array}$ & $\begin{array}{l}\text { SETDB1 mRNA was upregulated in primary } \\
\text { NSCLC tissues. SETDB1 and TP53 mRNA levels } \\
\text { were negatively correlated. }\end{array}$ & RT-qPCR & $\begin{array}{l}\text { SETDB1 is highly expressed in } \\
\text { NSCLC. }\end{array}$ \\
\hline \multirow{3}{*}{ Wang et al. $2019[50]$} & Oncomine database: NSCLC tissues $(n=1926)$. & $\begin{array}{l}\text { SETDB1 mRNA was upregulated in NSCLC } \\
\text { tissues. Higher expression of SETDB1 mRNA was } \\
\text { associated shorter overall survival in NSCLC } \\
\text { patients. }\end{array}$ & $\begin{array}{l}\text { Bioinformatics, } \\
\text { Kaplan-Meier analysis }\end{array}$ & $\begin{array}{l}\text { High mRNA levels of SETDB1 } \\
\text { as a prognostic marker of poor } \\
\text { survival in NSCLC patients. }\end{array}$ \\
\hline & $\begin{array}{c}\text { Primary NSCLC tissues }(n=9) \text { and paired adjacent } \\
\text { normal tissues }(n=9) .\end{array}$ & $\begin{array}{l}\text { SETDB1 was overexpressed in most paired NSCLC } \\
\text { tumors compared to non-tumor tissues. }\end{array}$ & WB & \multirow{2}{*}{$\begin{array}{l}\text { SETDB1 is highly expressed in } \\
\text { NSCLC. }\end{array}$} \\
\hline & Primary NSCLC tissues $(n=156)$. & $\begin{array}{c}\text { SETDB1 protein levels were elevated in NSCLC } \\
\text { tissues (SETDB1 was detected in the nucleus and } \\
\text { cytoplasm). }\end{array}$ & $\mathrm{IHC}$ & \\
\hline
\end{tabular}

Abbreviations: The Cancer Genome Atlas (TCGA), immunohistochemistry (IHC), fluorescence in situ hybridization (FISH), reverse transcription polymerase chain reaction (RT-qPCR),

Western blot (WB). 


\section{Discussion}

Lysine methylation is a key post-translational modification that regulates gene expression at different levels, ranging from transcriptional to post-transcriptional and translational. For instance, lysine methylation affects the stability, localization and activity of proteins, such as proteins involved in cell signaling pathways and in the transcriptional and post-transcriptional regulation of gene expression; TP53, NF- $\mathrm{B}$, YAP and STAT3 are some examples of important methylated proteins [58-61]. Therefore, lysine methylation and its regulators have a key impact on normal cell fate and its deregulation in disease, such as in cancer.

Histone lysine methylation plays important roles in lung cancer development [10]. Dynamic histone lysine methylation status is regulated by the interplay among histone methyltransferases (KMTs) or demethylases (KDMs). The genes coding for these enzymes may be subject to mutations, chromosomal deletions or amplifications, and these factors change the overall histone methylation/demethylation balance. For example, recent publications reported that SETDB1 is subject to gene amplification-associated activation in lung tumorigenesis [23]. SETDB1 might impact the cancer phenotype by acting on different substrates. Indeed, in addition to its best-known target, namely, H3K9, it is also known that SETDB1 methylates many other non-histone substrates with high relevance to lung cancer. These include the tumor suppressor TP53 and the kinase AKT [50,62]. Thus, SETDB1 overexpression in lung cancer cells could be crucial at different molecular levels, not only at the chromatin level.

Here, we asked whether SETDB1 overexpression was related to the clinical features of lung cancer patients with two major types of NSCLC, namely, adenocarcinoma and squamous cell carcinoma.

We analyzed 25 published gene transcriptomic datasets and found that SETDB1 mRNA level was significantly increased in NSCLC tissues compared to normal lung tissues. In many cases, the copy number gain or amplification of the SETDB1 gene locus in primary tumors was accompanied with elevated SETDB1 mRNA and protein levels [23,24,50,51,54]. SETDB1 was also found to be amplified and/or upregulated in several NSCLC cell lines (NCI-H1437, NCI-H1395, A549, Calu-1, SK-MES-1, SK-LU-1, SW-900, and PC14) $[20,23,54]$.

Our subgroup analyses for ADC and SCC showed higher SETDB1 mRNA levels in ADC as compared to SCC, while SETDB1 expression in both cancer subtypes was still significantly higher than in normal lung tissues. This is consistent with lower levels of SETDB1 amplification in SCC compared to ADC [49].

We observed no statistically significant correlation between the clinical stage of ADC or SCC and SETDB1 expression. Previously published studies differ on this issue. Indeed, Inoue et al. reported that SETDB1 amplification in ADC was associated with an advanced cancer stage [49]. In contrast, Lafuente-Sanchis et al. showed that high SETDB1 expression in NSCLC was observed the earliest cancer stages [51]. In all cases, amplification and a high level of expression of SETDB1 were associated with a shorter disease-free survival [49-51]. These discrepancies may be due to both the different selection criteria of the cases but also to a different number of patients included in these studies.

Several studies observed overexpression of SETDB1 in other types of tumors, like hepatocellular carcinoma and melanoma, which was associated with a poor prognosis [19,63,64]. Importantly, the silencing of SETDB1 was shown to inhibit cell proliferation, cell invasion, tumor growth and metastasis in different types of cancer [65,66]. In vitro and in vivo experiments showed that SETDB1 overexpression was associated with elevated cell growth rates and invasive potential of cancer cells in nude mouse models $[20,23,50,55]$. SETDB1 hyperactivation affects various signaling pathways, such as the WNT, MAPK, Toll-like receptors (TLRs), focal adhesion, and JAK-STAT pathways in lung cancer cells [24]. In particular, the WNT signaling pathway helps maintain cancer stem cells and correlates with an increased tumor growth and initial potential [67]. The major (canonical) WNT pathway signaling occurs through $\beta$-catenin [68]; abnormal expression of $\beta$-catenin is linked to the development of particular types of breast, colorectal, prostate and lung cancers [69]. Wang et al. demonstrated that SETDB1-mediated AKT methylation correlates with AKT hyperactivation in NSCLC, promotes tumor 
development and predicts poor outcome [50]. Chen et al. showed that SETDB1 negatively regulated the expression of TP53 [54]. Indeed, Lafuente-Sanchis et al., with multivariate analysis, confirmed the independent prognostic value of SETDB1 for patients with the early stage of NSCLC [51].

As many other oncogenes, in certain conditions SETDB1 can participate in tumor suppression: the expression of SETDB1 was significantly decreased in highly metastatic sublines of the CL1 lung cancer cell line (adenocarcinoma) [52], but at the same time SETDB1 mRNA was high in the primary tumor samples in the early stages of NSCLC compared to the advanced stages. Accordingly, Wu et al. reported not only a pro-oncogenic role of SETDB1, but also an anti-oncogenic role in different stages of lung carcinogenesis, which is probably related to the cellular model chosen [52]. Thus, SETDB1 could play different roles in lung tumorigenesis. A strong correlation exists between high SETDB1 expression and the earliest stage of NSCLC, supporting the role of the gene at least in the first step of lung tumorigenesis. At later stages, SETDB1 becomes dispensable for tumor progression and its expression diminishes, though it remains high compared to normal lung epithelial cells. This behavior is found with many oncogenes [70].

Our findings open up the possibility to use SETDB1 expression level as a marker for early detection of patients at early stages of NSCLC and as a potential drug target in these patients.

\section{Materials and Methods}

\subsection{Search Strategy for Microarray Databases in the Gene Expression Omnibus (GEO) Repository}

Available microarray datasets related to NSCLC were downloaded from the GEO repository (https: //www.ncbi.nlm.nih.gov/gds). The final date for inclusion was April 2019. The search strategy included the terms ("Carcinoma, Non-Small-Cell Lung" [Mesh]) AND ("Homo sapiens" [porgn:_txid9606]).

The inclusion criteria were the following: (1) enrolled data must be obtained from humans; (2) microarray datasets with information about SETDB1 expression; (3) the sample type is not cell lines; (4) sufficient information to calculate the standardized mean difference (SMD); (5) for association analyses between SETDB1 expression and NSCLC, two types of studies are included: (i) paired cancerous and adjacent non-cancerous tissues resected from NSCLC patients, (ii) cancerous specimens from NSCLC patients and normal specimens from a healthy control group. Importantly, the sample size must contain at least a ratio of 4:1 for cases and controls; (6) for clinical and pathological analyses, patients who had adenocarcinoma or squamous cell carcinoma with clinical information.

\subsection{Data Extraction}

Based on the inclusion criteria, the following detailed parameters were extracted: GEO accession number, PubMed identifier (PMID), sample type, cancer type (NSCLC, ADC or SCC), sample size, gender, age, cancer stage, smoking history and expression values of SETDB1, by using the tool GEO2R from the National Center for Biotechnology Information (NCBI).

\subsection{Statistical Analysis}

For each GEO dataset, the association between SETDB1 expression and NSCLC was assessed by a Student's t-test or a Mann-Whitney unpaired test based on normality distribution. Furthermore, to generate individual receiver operator characteristic (ROC) curves, the true positive (TP), false positive (FP), false negative (FN), and true negative (TN) values were estimated. All aforementioned analyses were performed using the Statistical Package for Social Sciences (SPSS Version 25, Chicago, IL, USA).

For meta-analysis, standardized mean difference (SMD) with $95 \%$ confidence interval ( $95 \% \mathrm{CI})$ was used as a summary statistic, considering the fact that all studies measured the same outcome but at different scales. Heterogeneity was calculated by means of Cochran's (Q) and Higgins's $\left(I^{2}\right)$ tests. The $I^{2}$ test was expressed as a ratio ranging from $0 \%$ to $100 \%$. If $I^{2}>30 \%$ and $p$-value $<0.05$, the random-effects model was selected. Otherwise, the fixed-effects model was selected. A significant Q-statistic $(p<0.10)$ indicated heterogeneity across studies. To further evaluate the probable sources of 
heterogeneity, subgroup analyses were carried out. The presence of publication bias was graphically examined using funnel plots and Egger's regression asymmetry tests. Data were analyzed using the Comprehensive Meta-Analysis version 2 program (Biostat, Englewood, NJ, USA 2004).

For diagnostic study, a summarized receiver operator characteristic curve (sROC) was constructed and the area under the sROC curve (AUC) was recorded, as well as the sensitivity and specificity. These analyses were performed using the MetaDiSc 1.4 software.

\subsection{Search Strategy for Peer-Reviewed Journals}

A systematic review of electronic databases (Pubmed, EBI-EMBL, Web of Science, Embase, Bibliovie and Cochrane Library) was done independently by two experts. The final date for inclusion was April 2019. The search included publications about the association of SETDB1 and NSCLC. The search strategy used MeSH terms ("Carcinoma, Non-Small-Cell Lung"[Mesh]) AND ("SETDB1 protein, human" [Supplementary Concept]). Only manuscripts published in a peer-reviewed journal as a full paper were included. Summaries or abstracts were not accepted.

\section{Conclusions}

Epigenetic mechanisms and regulators are often deregulated in human disease conditions. Thus, epigenetic mechanisms have gained paramount importance in biomedical research, since their reversibility provides new possibilities in therapeutic intervention. On the other hand, their expression status could have a prognostic and diagnostic value. Here, we tested the clinical significance of SETDB1 mRNA level in lung cancer subtypes. Our overall pooled meta-analysis outcome revealed higher levels of SETDB1 mRNA in NSCLC as compared to non-cancerous control tissues. Interestingly, SETDB1 mRNA level was higher in tissues from NSCLC patients who were current or former smokers compared to non-smokers. Together, our findings suggest the possibility to use SETDB1 mRNA level as a marker for NSCLC early detection and as a potential druggable target in these patients.

Supplementary Materials: The following are available online at http://www.mdpi.com/2072-6694/11/8/1134/s1, Figure S1: Box plots displaying the expression levels of SETDB1 mRNA between NSCLC and non-tumor samples for each GEO dataset, Figure S2: Funnel plots for main meta-analyses performed., Figure S3: (A) Forest plot of the association of SETDB1 mRNA level with NSCLC patients reported as smokers compared to non-smoker patients, (B) Forest plot of association between SETDB1 mRNA level and NSCLC patients carrying mutations for TP53 gene, Figure S4: Individual ROC curves showing discriminative yield of SETDB1 mRNA level for NSCLC for each GEO dataset, Figure S5: The combined sensitivity and specificity showing moderate discriminative yield of SETDB1 mRNA expression for NSCLC, Figure S6: Workflow of the study selection for qualitative synthesis, Table S1: Overview of additional datasets selected from GEO for clinicopathological analyses, Table S2: Literature review about SETDB1 status in cell lines and xenograft models.

Author Contributions: Conceptualization, P.C.-T., S.A.-S.; methodology, P.C.-T., V.Z., O.-M.P.-F.; validation, W.M., S.R.-C.; investigation, P.C.-T., V.Z., O.-M.P.-F., S.A.-S.; writing-original draft preparation, P.C.-T., V.Z. O.-M.P.-F.; writing-review and editing, S.A.-S., W.M., S.R.-C.; project administration, S.A.-S.; funding acquisition, S.A.-S.

Funding: Work in Ait-Si-Ali's Lab was supported by the Fondation pour la Recherche Medicale (FRM, «Equipe FRM » grant \# DEQ20160334922); Association Française contre les Myopathies Telethon (AFM-Telethon, grant \# 22480); Institut National du Cancer (INCa, grant \# 2012-1-PL BIO-03-CNRS B-1); Agence Nationale de la Recherche (ANR, " MuSIC » grant \# ANR-17-CE12-0010-01), Université Paris Diderot and the "Who Am I?" Laboratory of Excellence, \# ANR-11-LABX-0071, funded by the French Government through its "Investments for the Future" program, operated by the ANR under grant \#ANR-11-IDEX-0005-01. P.C-T has been supported by the Colombian Administrative Department of Science, Technology and Innovation (COLCIENCIAS); Universidad del Rosario (Becas para Apoyo para Estudiantes Doctorales 2017); Colombian Institute of Educational Credit and Technical Studies Abroad (ICETEX); French Government Agency Campus France (Eiffel Excellence Scholarship Program); Fondation ARC pour la Recherche sur le Cancer and LABEX “Who am I?" (Université de Paris-Université Paris Diderot). VZ is supported by ANSES and ANR grants.

Conflicts of Interest: The authors declare no conflict of interest.

\section{References}

1. Barta, J.A.; Powell, C.A.; Wisnivesky, J.P. Global Epidemiology of Lung Cancer. Ann. Glob. Heal. $2019,85$. [CrossRef] [PubMed] 
2. Ellis, P.M.; Vandermeer, R. Delays in the diagnosis of lung cancer. J. Thorac. Dis. 2011, 3, 183. [PubMed]

3. Zhao, H.; Wang, J.; Kong, X.; Li, E.; Liu, Y.; Du, X.; Kang, Z.; Tang, Y.; Kuang, Y.; Yang, Z.; et al. CD47 Promotes Tumor Invasion and Metastasis in Non-small Cell Lung Cancer. Sci. Rep. 2016, 6, 29719. [CrossRef] [PubMed]

4. Langevin, S.M.; Kratzke, R.A.; Kelsey, K.T. Epigenetics of lung cancer. Transl. Res. 2015, 165, 74-90. [CrossRef] [PubMed]

5. Cohen, I.; Poręba, E.; Kamieniarz, K.; Schneider, R. Histone modifiers in cancer: Friends or foes? Genes Cancer 2011, 2, 631-647. [CrossRef] [PubMed]

6. Mozzetta, C.; Boyarchuk, E.; Pontis, J.; Ait-Si-Ali, S. Sound of silence: The properties and functions of repressive Lys methyltransferases. Nat. Rev. Mol. Cell Biol. 2015, 16, 499-513. [CrossRef]

7. Greer, E.L.; Shi, Y. Histone methylation: A dynamic mark in health, disease and inheritance. Nat. Rev. Genet. 2012, 13, 343-357. [CrossRef]

8. Ellinger, J.; Kahl, P.; von der Gathen, J.; Rogenhofer, S.; Heukamp, L.C.; GÃ $\frac{1}{4}$ tgemann, I.; Walter, B.; Hofstädter, F.; Büttner, R.; Müller, S.C.; et al. Global levels of histone modifications predict prostate cancer recurrence. Prostate 2010, 70, 61-69. [CrossRef]

9. Seligson, D.B.; Horvath, S.; McBrian, M.A.; Mah, V.; Yu, H.; Tze, S.; Wang, Q.; Chia, D.; Goodglick, L.; Kurdistani, S.K.; et al. Global levels of histone modifications predict prognosis in different cancers. Am. J. Pathol. 2009, 174, 1619-1628. [CrossRef]

10. Song, J.S.; Kim, Y.S.; Kim, D.K.; Park, S.I.; Jang, S.J. Global histone modification pattern associated with recurrence and disease-free survival in non-small cell lung cancer patients. Pathol. Int. 2012, 62, 182-190. [CrossRef]

11. Van Rechem, C.; Whetstine, J.R. Examining the impact of gene variants on histone lysine methylation. Biochim. Biophys. Acta 2014, 1839, 1463-1476. [CrossRef] [PubMed]

12. Dodge, J.E.; Kang, Y.-K.; Beppu, H.; Lei, H.; Li, E. Histone H3-K9 methyltransferase ESET is essential for early development. Mol. Cell. Biol. 2004, 24, 2478-2486. [CrossRef] [PubMed]

13. Lawson, K.A.; Teteak, C.J.; Gao, J.; Li, N.; Hacquebord, J.; Ghatan, A.; Zielinska-Kwiatkowska, A.; Song, G.; Chansky, H.A.; Yang, L.; et al. ESET histone methyltransferase regulates osteoblastic differentiation of mesenchymal stem cells during postnatal bone development. FEBS Lett. 2013, 587, 3961-3967. [CrossRef] [PubMed]

14. Beyer, S.; Pontis, J.; Schirwis, E.; Battisti, V.; Rudolf, A.; Le Grand, F.; Ait-Si-Ali, S. Canonical Wnt signalling regulates nuclear export of Setdb1 during skeletal muscle terminal differentiation. Cell Discov. 2016, 2, 16037. [CrossRef] [PubMed]

15. Yeap, L.-S.; Hayashi, K.; Surani, M.A. ERG-associated protein with SET domain (ESET)-Oct4 interaction regulates pluripotency and represses the trophectoderm lineage. Epigenet. Chromatin 2009, 2, 12. [CrossRef]

16. Bilodeau, S.; Kagey, M.H.; Frampton, G.M.; Rahl, P.B.; Young, R.A. SetDB1 contributes to repression of genes encoding developmental regulators and maintenance of ES cell state. Genes Dev. 2009, 23, 2484-2489. [CrossRef]

17. Lohmann, F.; Loureiro, J.; Su, H.; Fang, Q.; Lei, H.; Lewis, T.; Yang, Y.; Labow, M.; Li, E.; Chen, T.; et al. KMT1E mediated H3K9 methylation is required for the maintenance of embryonic stem cells by repressing trophectoderm differentiation. Stem. Cells 2010, 28, 201-212. [CrossRef]

18. Reya, T.; Morrison, S.J.; Clarke, M.F.; Weissman, I.L. Stem cells, cancer, and cancer stem cells. Nature 2001, 414, 105-111. [CrossRef]

19. Ceol, C.J.; Houvras, Y.; Jane-Valbuena, J.; Bilodeau, S.; Orlando, D.A.; Battisti, V.; Fritsch, L.; Lin, W.M.; Hollmann, T.J.; Ferré, F.; et al. The histone methyltransferase SETDB1 is recurrently amplified in melanoma and accelerates its onset. Nature 2011, 471, 513-517. [CrossRef]

20. Watanabe, H.; Soejima, K.; Yasuda, H.; Kawada, I.; Nakachi, I.; Yoda, S.; Naoki, K.; Ishizaka, A. Deregulation of histone lysine methyltransferases contributes to oncogenic transformation of human bronchoepithelial cells. Cancer Cell Int. 2008, 8, 15. [CrossRef]

21. Li, H.; Rauch, T.; Chen, Z.-X.; Szabó, P.E.; Riggs, A.D.; Pfeifer, G.P. The histone methyltransferase SETDB1 and the DNA methyltransferase DNMT3A interact directly and localize to promoters silenced in cancer cells. J. Biol. Chem. 2006, 281, 19489-19500. [CrossRef] [PubMed]

22. Kokura, K.; Sun, L.; Bedford, M.T.; Fang, J. Methyl-H3K9-binding protein MPP8 mediates E-cadherin gene silencing and promotes tumour cell motility and invasion. EMBO J. 2010, 29,3673-3687. [CrossRef] [PubMed] 
23. Rodriguez-Paredes, M.; de Paz, A.M.; Simó-Riudalbas, L.; Sayols, S.; Moutinho, C.; Moran, S.; Villanueva, A.; Vázquez-Cedeira, M.; Lazo, P.A.; Carneiro, F.; et al. Gene amplification of the histone methyltransferase SETDB1 contributes to human lung tumorigenesis. Oncogene 2014, 33, 2807-2813. [CrossRef] [PubMed]

24. Sun, Q.-Y.; Ding, L.-W.; Xiao, J.-F.; Chien, W.; Lim, S.-L.; Hattori, N.; Goodglick, L.; Chia, D.; Mah, V.; Alavi, M.; et al. SETDB1 accelerates tumourigenesis by regulating the WNT signalling pathway. J. Pathol. 2015, 235, 559-570. [CrossRef] [PubMed]

25. Selamat, S.A.; Chung, B.S.; Girard, L.; Zhang, W.; Zhang, Y.; Campan, M.; Siegmund, K.D.; Koss, M.N.; Hagen, J.A.; Lam, W.L.; et al. Genome-scale analysis of DNA methylation in lung adenocarcinoma and integration with mRNA expression. Genome Res. 2012, 22, 1197-1211. [CrossRef] [PubMed]

26. Sanchez-Palencia, A.; Gomez-Morales, M.; Gomez-Capilla, J.A.; Pedraza, V.; Boyero, L.; Rosell, R.; Fárez-Vidal, M.E. Gene expression profiling reveals novel biomarkers in nonsmall cell lung cancer. Int. J. Cancer 2011, 129, 355-364. [CrossRef] [PubMed]

27. Lu, T.-P.; Tsai, M.-H.; Lee, J.-M.; Hsu, C.-P.; Chen, P.-C.; Lin, C.-W.; Shih, J.Y.; Yang, P.C.; Hsiao, C.K.; Lai, L.C.; et al. Identification of a novel biomarker, SEMA5A, for non-small cell lung carcinoma in nonsmoking women. Cancer Epidemiol. Biomark. Prev. 2010, 19, 2590-2597. [CrossRef] [PubMed]

28. Brouwer-Visser, J.; Cheng, W.-Y.; Bauer-Mehren, A.; Maisel, D.; Lechner, K.; Andersson, E.; Dudley, J.T.; Milletti, F. Regulatory T-cell Genes Drive Altered Immune Microenvironment in Adult Solid Cancers and Allow for Immune Contextual Patient Subtyping. Cancer Epidemiol. Biomark. Prev. 2018, 27, 103-112. [CrossRef] [PubMed]

29. Robles, A.I.; Arai, E.; Mathé, E.A.; Okayama, H.; Schetter, A.J.; Brown, D.; Petersen, D.; Bowman, E.D.; Noro, R.; Welsh, J.A.; et al. An Integrated Prognostic Classifier for Stage I Lung Adenocarcinoma Based on mRNA, microRNA, and DNA Methylation Biomarkers. J. Thorac. Oncol. 2015, 10, 1037-1048. [CrossRef]

30. Pickup, M.E.; Dixon, J.S.; Lowe, J.R.; Wright, V. Serum histidine in rheumatoid arthritis: Changes induced by antirheumatic drug therapy. J. Rheumatol. 1980, 7, 71-76.

31. Meister, M.; Belousov, A.; Xu, E.; Schnabel, P.; Warth, A.; Hoffmann, H.; Dienemann, H.; Riedlinger, J.; Bodenmueller, H.; Zolg, W.; et al. Intra-tumor Heterogeneity of Gene Expression Profiles in Early Stage Non-Small Cell Lung Cancer. J. Bioinf. Res. Stud. 2014, 1, 1.

32. Kadara, H.; Fujimoto, J.; Yoo, S.-Y.; Maki, Y.; Gower, A.C.; Kabbout, M.; Garcia, M.M.; Chow, C.W.; Chu, Z.; Mendoza, G.; et al. Transcriptomic architecture of the adjacent airway field cancerization in non-small cell lung cancer. J. Natl. Cancer Inst. 2014, 106, dju004. [CrossRef] [PubMed]

33. Kabbout, M.; Garcia, M.M.; Fujimoto, J.; Liu, D.D.; Woods, D.; Chow, C.-W.; Mendoza, G.; Momin, A.A.; James, B.P.; Solis, L.; et al. ETS2 mediated tumor suppressive function and MET oncogene inhibition in human non-small cell lung cancer. Clin. Cancer Res. 2013, 19, 3383-3395. [CrossRef] [PubMed]

34. Lo, F.-Y.; Chang, J.-W.; Chang, I.-S.; Chen, Y.-J.; Hsu, H.-S.; Huang, S.-F.K.; Tsai, F.Y.; Jiang, S.S.; Kanteti, R.; Nandi, S.; et al. The database of chromosome imbalance regions and genes resided in lung cancer from Asian and Caucasian identified by array-comparative genomic hybridization. BMC Cancer 2012, 12, 235. [CrossRef] [PubMed]

35. Lin, J.; Marquardt, G.; Mullapudi, N.; Wang, T.; Han, W.; Shi, M.; Keller, S.; Zhu, C.; Locker, J.; Spivack, S.D. Lung cancer transcriptomes refined with laser capture microdissection. Am. J. Pathol. 2014, 184, 2868-2884. [CrossRef] [PubMed]

36. Landi, M.T.; Dracheva, T.; Rotunno, M.; Figueroa, J.D.; Liu, H.; Dasgupta, A.; Mann, F.E.; Fukuoka, J.; Hames, M.; Bergen, A.W.; et al. Gene expression signature of cigarette smoking and its role in lung adenocarcinoma development and survival. PLoS ONE 2008, 3, e1651. [CrossRef] [PubMed]

37. Spira, A.; Beane, J.E.; Shah, V.; Steiling, K.; Liu, G.; Schembri, F.; Gilman, S.; Dumas, Y.M.; Calner, P.; Sebastiani, P.; et al. Airway epithelial gene expression in the diagnostic evaluation of smokers with suspect lung cancer. Nat. Med. 2007, 13, 361-366. [CrossRef]

38. Su, L.-J.; Chang, C.-W.; Wu, Y.-C.; Chen, K.-C.; Lin, C.-J.; Liang, S.-C.; Lin, C.H.; Whang-Peng, J.; Hsu, S.L.; Chen, C.H.; et al. Selection of DDX5 as a novel internal control for Q-RT-PCR from microarray data using a block bootstrap re-sampling scheme. BMC Genom. 2007, 8, 140. [CrossRef]

39. Stearman, R.S.; Dwyer-Nield, L.; Zerbe, L.; Blaine, S.A.; Chan, Z.; Bunn, P.A.; Johnson, G.L.; Hirsch, F.R.; Merrick, D.T.; Franklin, W.A.; et al. Analysis of orthologous gene expression between human pulmonary adenocarcinoma and a carcinogen-induced murine model. Am. J. Pathol. 2005, 167, 1763-1775. [CrossRef] 
40. Baty, F.; Facompré, M.; Kaiser, S.; Schumacher, M.; Pless, M.; Bubendorf, L.; Savic, S.; Marrer, E.; Budach, W.; Buess, M.; et al. Gene profiling of clinical routine biopsies and prediction of survival in non-small cell lung cancer. Am. J. Respir. Crit. Care Med. 2010, 181, 181-188. [CrossRef]

41. Dehan, E.; Ben-Dor, A.; Liao, W.; Lipson, D.; Frimer, H.; Rienstein, S.; Simansky, D.; Krupsky, M.; Yaron, P.; Friedman, E.; et al. Chromosomal aberrations and gene expression profiles in non-small cell lung cancer. Lung Cancer 2007, 56, 175-184. [CrossRef] [PubMed]

42. Hou, J.; Aerts, J.; den Hamer, B.; van Ijcken, W.; den Bakker, M.; Riegman, P.; van der Leest, C.; van der Spek, P.; Foekens, J.A.; Hoogsteden, H.C.; et al. Gene expression-based classification of non-small cell lung carcinomas and survival prediction. PLOS ONE 2010, 5, e10312. [CrossRef] [PubMed]

43. Marwitz, S.; Depner, S.; Dvornikov, D.; Merkle, R.; Szczygieł, M.; Müller-Decker, K.; Lucarelli, P.; Wäsch, M.; Mairbäurl, H.; Rabe, K.F.; et al. Downregulation of the TGF $\beta$ Pseudoreceptor BAMBI in Non-Small Cell Lung Cancer Enhances TGF $\beta$ Signaling and Invasion. Cancer Res. 2016, 76, 3785-3801. [CrossRef] [PubMed]

44. Chang, I.-S.; Jiang, S.S.; Yang, J.C.-H.; Su, W.-C.; Chien, L.-H.; Hsiao, C.-F.; Lee, J.H.; Chen, C.Y.; Chen, C.H.; Chang, G.C.; et al. Genetic Modifiers of Progression-Free Survival in Never-Smoking Lung Adenocarcinoma Patients Treated with First-Line Tyrosine Kinase Inhibitors. Am. J. Respir. Crit. Care Med. 2017, 195, 663-673. [CrossRef] [PubMed]

45. Fujiwara, T.; Hiramatsu, M.; Isagawa, T.; Ninomiya, H.; Inamura, K.; Ishikawa, S.; Ushijima, M.; Matsuura, M.; Jones, M.H.; Shimane, M.; et al. ASCL1-coexpression profiling but not single gene expression profiling defines lung adenocarcinomas of neuroendocrine nature with poor prognosis. Lung Cancer 2012, 75, 119-125. [CrossRef] [PubMed]

46. Boelens, M.C.; van den Berg, A.; Fehrmann, R.S.N.; Geerlings, M.; de Jong, W.K.; te Meerman, G.J.; Sietsma, H.; Timens, W.; Postma, D.S.; Groen, H.J. Current smoking-specific gene expression signature in normal bronchial epithelium is enhanced in squamous cell lung cancer. J. Pathol. 2009, 218, 182-191. [CrossRef]

47. Wei, T.-Y.W.; Juan, C.-C.; Hisa, J.-Y.; Su, L.-J.; Lee, Y.-C.G.; Chou, H.-Y.; Chen, J.M.; Wu, Y.C.; Chiu, S.C.; $\mathrm{Hsu}$, C.P.; et al. Protein arginine methyltransferase 5 is a potential oncoprotein that upregulates G1 cyclins/cyclin-dependent kinases and the phosphoinositide 3-kinase/AKT signaling cascade. Cancer Sci. 2012, 103, 1640-1650. [CrossRef]

48. Mitchell, K.A.; Zingone, A.; Toulabi, L.; Boeckelman, J.; Ryan, B.M. Comparative Transcriptome Profiling Reveals Coding and Noncoding RNA Differences in NSCLC from African Americans and European Americans. Clin. Cancer Res. 2017, 23, 7412-7425. [CrossRef]

49. Inoue, Y.; Matsuura, S.; Kurabe, N.; Kahyo, T.; Mori, H.; Kawase, A.; Karayama, M.; Inui, N.; Funai, K.; Shinmura, K.; et al. Clinicopathological and Survival Analysis of Japanese Patients with Resected Non-Small-Cell Lung Cancer Harboring NKX2-1, SETDB1, MET, HER2, SOX2, FGFR1, or PIK3CA Gene Amplification. J. Thorac. Oncol. 2015, 10, 1590-1600. [CrossRef]

50. Wang, G.; Long, J.; Gao, Y.; Zhang, W.; Han, F.; Xu, C.; Sun, L.; Yang, S.C.; Lan, J.; Hou, Z.; et al. SETDB1-mediated methylation of Akt promotes its K63-linked ubiquitination and activation leading to tumorigenesis. Nat. Cell Biol. 2019, 21, 214-225. [CrossRef]

51. Lafuente-Sanchis, A.; Zúñiga, Á.; Galbis, J.M.; Cremades, A.; Estors, M.; Martínez-Hernández, N.J.; Carretero, J. Prognostic value of ERCC1, RRM1, BRCA1 and SETDB1 in early stage of non-small cell lung cancer. Clin. Transl. Oncol. 2016, 18, 798-804. [CrossRef] [PubMed]

52. Wu, P.-C.; Lu, J.-W.; Yang, J.-Y.; Lin, I.-H.; Ou, D.-L.; Lin, Y.-H.; Chou, K.H.; Huang, W.F.; Wang, W.P.; Huang, Y.L.; et al. H3K9 histone methyltransferase, KMT1E/SETDB1, cooperates with the SMAD2/3 pathway to suppress lung cancer metastasis. Cancer Res. 2014, 74, 7333-7343. [CrossRef] [PubMed]

53. Lee, J.-K.; Kim, K.-C. DZNep, inhibitor of S-adenosylhomocysteine hydrolase, down-regulates expression of SETDB1 H3K9me3 HMTase in human lung cancer cells. Biochem. Biophys. Res. Commun. 2013, 438, 647-652. [CrossRef] [PubMed]

54. Chen, B.; Wang, J.; Wang, J.; Wang, H.; Gu, X.; Tang, L.; Feng, X. A regulatory circuitry comprising TP53, miR-29 family, and SETDB1 in non-small cell lung cancer. Biosci. Rep. 2018, 38, BSR20180678. [CrossRef] [PubMed]

55. Na, H.-H.; Kim, K.-C. SETDB1-mediated FosB regulation via ERK2 is associated with an increase in cell invasiveness during anticancer drug treatment of A549 human lung cancer cells. Biochem. Biophys. Res. Commun. 2018, 495, 512-518. [CrossRef] [PubMed] 
56. Al Emran, A.; Marzese, D.M.; Menon, D.R.; Stark, M.S.; Torrano, J.; Hammerlindl, H.; Zhang, G.; Brafford, P.; Salomon, M.P.; Nelson, N.; et al. Distinct histone modifications denote early stress-induced drug tolerance in cancer. Oncotarget 2018, 9, 8206-8222. [CrossRef] [PubMed]

57. Noh, H.-J.; Kim, K.-A.; Kim, K.-C. p53 down-regulates SETDB1 gene expression during paclitaxel induced-cell death. Biochem. Biophys. Res. Commun. 2014, 446, 43-48. [CrossRef]

58. Kruse, J.-P.; Gu, W. Modes of p53 Regulation. Cell 2009, 137, 609-622. [CrossRef]

59. Chen, X.; El Gazzar, M.; Yoza, B.K.; McCall, C.E. The NF-кB Factor RelB and Histone H3 Lysine Methyltransferase G9a Directly Interact to Generate Epigenetic Silencing in Endotoxin Tolerance. J. Biol. Chem. 2009, 284, 27857-27865. [CrossRef]

60. Fang, L.; Teng, H.; Wang, Y.; Liao, G.; Weng, L.; Li, Y.; Wang, X.; Jin, J.; Jiao, C.; Chen, L.; et al. SET1A-Mediated Mono-Methylation at K342 Regulates YAP Activation by Blocking Its Nuclear Export and Promotes Tumorigenesis. Cancer Cell 2018, 34, 103-118. [CrossRef]

61. Kim, E.; Kim, M.; Woo, D.-H.; Shin, Y.; Shin, J.; Chang, N.; Oh, Y.T.; Kim, H.; Rheey, J.; Nakano, I.; et al. Phosphorylation of EZH2 Activates STAT3 Signaling via STAT3 Methylation and Promotes Tumorigenicity of Glioblastoma Stem-like Cells. Cancer Cell 2013, 23, 839-852. [CrossRef] [PubMed]

62. Fei, Q.; Shang, K.; Zhang, J.; Chuai, S.; Kong, D.; Zhou, T.; Fu, S.; Liang, Y.; Li, C.; Chen, Z.; et al. Histone methyltransferase SETDB1 regulates liver cancer cell growth through methylation of p53. Nat. Commun. 2015, 6, 8651. [CrossRef] [PubMed]

63. Wong, C.-M.; Wei, L.; Law, C.-T.; Ho, D.W.-H.; Tsang, F.H.-C.; Au, S.L.-K.; Sze, K.M.; Lee, J.M.; Wong, C.C.; $\mathrm{Ng}$, I.O.; et al. Up-regulation of histone methyltransferase SETDB1 by multiple mechanisms in hepatocellular carcinoma promotes cancer metastasis. Hepatology 2016, 63, 474-487. [CrossRef] [PubMed]

64. Robbez-Masson, L.; Tie, C.H.C.; Rowe, H.M. Cancer cells, on your histone marks, get SETDB1, silence retrotransposons, and go! J. Cell Biol. 2017, 216, 3429-3431. [CrossRef] [PubMed]

65. Sun, Y.; Wei, M.; Ren, S.-C.; Chen, R.; Xu, W.-D.; Wang, F.-B.; Lu, J.; Shen, J.; Yu, Y.W.; Hou, J.G.; et al. Histone methyltransferase SETDB1 is required for prostate cancer cell proliferation, migration and invasion. Asian. J. Androl. 2014, 16, 319-324. [CrossRef]

66. Zhang, H.; Cai, K.; Wang, J.; Wang, X.; Cheng, K.; Shi, F.; Jiang, L.; Zhang, Y.; Dou, J. MiR-7, inhibited indirectly by lincRNA HOTAIR, directly inhibits SETDB1 and reverses the EMT of breast cancer stem cells by downregulating the STAT3 pathway. Stem Cells 2014, 32, 2858-2868. [CrossRef]

67. Vaughan, A.E.; Halbert, C.L.; Wootton, S.K.; Miller, A.D. Lung cancer in mice induced by the jaagsiekte sheep retrovirus envelope protein is not maintained by rare cancer stem cells, but tumorigenicity does correlate with Wnt pathway activation. Mol. Cancer Res. 2012, 10, 86-95. [CrossRef]

68. Stewart, D.J. Wnt Signaling Pathway in Non-Small Cell Lung Cancer. JNCI J. Natl. Cancer Inst. 2014, 106, djt356. [CrossRef]

69. Shang, S.; Hua, F.; Hu, Z.-W. The regulation of $\beta$-catenin activity and function in cancer: Therapeutic opportunities. Oncotarget 2017, 8, 33972-33989. [CrossRef]

70. Stepanenko, A.A.; Vassetzky, Y.S.; Kavsan, V.M. Antagonistic functional duality of cancer genes. Gene 2013, 529, 199-207. [CrossRef]

(C) 2019 by the authors. Licensee MDPI, Basel, Switzerland. This article is an open access article distributed under the terms and conditions of the Creative Commons Attribution (CC BY) license (http://creativecommons.org/licenses/by/4.0/). 